IRSH 53 (2008), pp. 459-484 doi:I0.I0I7/So020859008003544

(C) 2008 Internationaal Instituut voor Sociale Geschiedenis

\title{
“Travelling with Ballin": The Impact of American Immigration Policies on Jewish Transmigration within Central Europe, I 880-I9I4*
}

\author{
T OB I A B R I N M A N N
}

Summary: The restrictive immigration policies enacted in I92 I and I 924 by the United States Congress had strong roots in the period before World War I. This is not a new thesis. But this article transcends the confines of American history and looks at the impact of increasingly restrictive American immigration policies in central Europe since the early I880s. It describes in detail how German state authorities and private steamship lines constructed an increasingly hermetic transit corridor through Germany, making sure that only persons who would not be rejected by the American immigration inspectors could enter. The wellorganized and profitable transit migration system broke down in i9i4. The repercussions of the closing American doors forced the Weimar Republic to take a less restrictive line towards foreign aliens than its imperial predecessor, as large numbers of migrants were stranded in permanent transit.

In the early morning of a summer day in I9 10 a suburban train crashed into a rear coach of another train, which was waiting at a signal in central Berlin. The damage was limited, but several passengers required medical treatment. The damaged train had to make an unscheduled stop at Friedrichstrasse, one of the busiest traffic intersections of the bustling German capital. On the same day the midday editions of the local press briefly covered the incident. It was a "strange sight"; the wounded passengers who were stumbling on to the platform were obviously out of place in central Berlin: "poor Poles, the women in multi-coloured blouses and skirts with the red label 'Hamburg' fixed to their clothes, the men in cheap suits". After being treated, the wounded were dispatched to the railway station at Ruhleben. ${ }^{\mathrm{I}}$ Another paper even recorded the names and destinations of the eight Polish

\footnotetext{
* I would like to thank Joachim Schloer and Jochen Oltmer for pointing me to sources, and for useful feedback by Dorothee Schneider, Marlou Schrover, Sigrid Wadauer, and three anonymous reviewers for this journal. The Hamburg Staff Exchange at the University of Southampton enabled me to conduct research for this article at the Hamburg State Archive in 2007.

I. B[erliner] Z[eitung] am Mittag, 2 August 1910 (noon edition).
} 


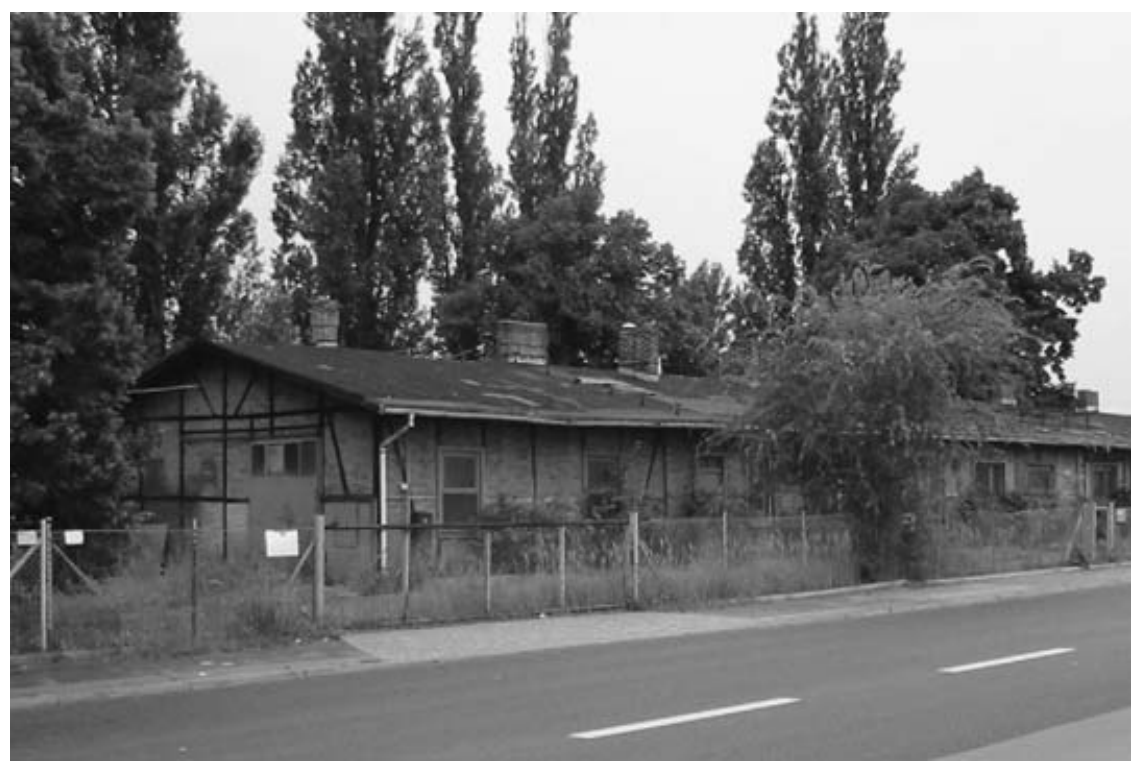

Figure I. Ruhleben station building, Berlin, 2006.

Photograph by the author.

women, children, and men who received medical care; most were en route to destinations in the United States. ${ }^{2}$

The damaged train was not a regular train; its doors were sealed. Normally these passengers would not have been visible to the Berlin public. The train originated in Thorn near the German border with the Russian empire and its destination was the port of Hamburg. The only scheduled stop was Ruhleben near Berlin, a small suburban station that contemporary maps depicted as Auswandererbahnhof [emigrant railway station]. Today, trains on the busy railway between Berlin and Hamburg rush past Ruhleben; the platform has been demolished. Surprisingly, in the midst of an industrial area, the inconspicuous station building is still standing. But between I89I and I9I4 thousands of "emigrant trains" stopped in Ruhleben, on the route between Germany's eastern border and the overseas ports of Hamburg and Bremen, or the western border. The number of migrants who were processed at Ruhleben annually was impressive: in most years between 1900 and I9I4 more than 100,000, mostly Jews and Poles, passed through Ruhleben, and in I9I 3 alone a staggering $193,302 .^{3}$

2. Berliner Lokalanzeiger, 2 August I910 (noon edition).

3. Karin Schulz, "Der Auswandererbahnhof Ruhleben: Nadelöhr zum Westen", in Die Reise nach Berlin (exhibition catalogue) (Berlin, 1987), pp. 237-24I; Michael Just, Ost- und 
In the research literature the immigration experience of Jews, Poles, Ukrainians, ethnic Germans, and other eastern Europeans between i 880 and I9I 4 in America, and also in Britain, France, Germany, and Palestine stands out. Only a few authors have dealt with the migration process itself. ${ }^{4}$ It is not surprising, therefore, that scholars working on crossborder transit migration in central Europe still have to rely on several key studies dating from the r 940 s and earlier. ${ }^{5}$ The dominance of the nationstate paradigm, even in modern Jewish history, partly explains this gap. The national perspective tends to obscure the transnational, even global, dimension of mass movement and often goes hand in hand with a lack of awareness of the interrelation between the migration policies of different states and the impact of economic, social, and cultural factors across and far beyond national borders. ${ }^{6}$

Surprisingly little is known about the reasons why and how migrants travelled on certain paths across uncontrolled or so-called green borders, through railway stations, port cities, across seas and oceans - and how much choice they had over the directions they took. Of course, arriving immigrants were more visible than migrants in transit, except when routine processes were disrupted. The small Berlin train crash provides a rare keyhole perspective on the handling of mass transit migration from eastern Europe through Germany to the West, especially to the United States. In hindsight, Ellis Island, the point of passage into America, situated spectacularly in the shadow of the Statue of Liberty and opposite Manhattan, has a much higher significance as a symbol of immigration to America than the often inconspicuous points of transit:

südosteuropäische Amerikawanderung: I88I-19I4. Transitprobleme in Deutschland und Aufnabme in den Vereinigten Staaten (Stuttgart, 1988), p. 37.

4. Dirk Hoerder, Cultures in Contact: World Migrations in the Second Millennium (Durham, NC, 2002).

5. Leopold Caro, Auswanderung und Auswanderungspolitik in Österreich (Leipzig, 1909); Hans Weichmann, Die Auswanderung aus Österreich und Rußland über die Deutschen Häfen (Berlin, I9I3); Bernhard Karlsberg, Geschichte und Bedeutung der deutschen Durchwandererkontrolle (Hamburg [etc.], I922); Alexander and Eugen Kulischer, Kriegs- und Wanderzüge: Weltgeschichte als Völkerbewegung (Berlin [etc.], I932); Eugene Kulischer, Europe on the Move: War and Population Changes 1917-47 (New York, 1948); Mark Wischnitzer, To Dwell in Safety: The Story of Jewish Migration since I 800 (Philadelphia, PA, I948); Simon Kuznets, "Immigration of Russian Jews to the United States: Background and Structure", Perspectives in American History, 9 (1975), pp. 35-I24; Zosa Szajkowski, "Suffering of Jewish Emigrants to America in Transit through Germany", Jewish Social Studies, 29 (1977), pp. I05-1 I6; Pamela Susan Nadell, The Journey to America by Steam: The Jews of Eastern Europe in Transition, unpublished Ph.D. dissertation, Ohio State University (Columbus, OH, I982); Birgit Ottmüller-Wetzel, Auswanderung über Hamburg: Die HAPAG und die Auswanderung nach Nordamerika I870-19I4 (Berlin, I986); Just, Ost- und südosteuropäische Amerikawanderung. 6. Adam Mckeown, "Global Migration, I846-1940", Journal of World History, is (2004), pp. I55-190. 
stations, waiting rooms, primitive makeshift facilities for transmigrants near or at European railway stations, police cells, internment camps, quarantine barracks at port cities, and control posts along borders that vanished after I9I 8 .

This article concentrates on moving eastern Europeans, especially Jews, en route to the United States, in Germany before and after the "Great War". "Eastern Europe" here refers to the Russian and Austro-Hungarian empires and Romania. In the following paragraphs the concrete impact of American immigration restrictions beyond America's shores will be examined in some detail. Apart from German policies towards transmigrants, the roles of transport companies, migrant aid societies, and the agency of migrants themselves will be considered. Important sources are older works on transmigration and, of course, newspapers. Routine movements, even of huge numbers of people, rarely made headline news. Interruptions of ordinary movements, however, concerns over security, and occasionally, the ill-treatment of migrants were newsworthy. Since transmigrants were increasingly isolated from the rest of the population, and thus from the public sphere, other sources such as memoirs, the reports of immigrant aid societies, and not least the files of transport companies and of police, government, and border officials were consulted.

Germany, the focus of this article, was not the only country affected by mass transit migration from eastern Europe between the second half of the nineteenth and the first half of the twentieth centuries. Future research will have to assess whether the massive controls in Germany served as an effective filter so that primarily "unproblematic" eastern European migrants, who had been screened, left Germany across the western border to ports in the Netherlands, France, Belgium, Britain, and Canada. Migrants from the Russian empire could bypass Germany, departing from the Baltic port of Libau for British and Scandinavian ports (especially Hull and Copenhagen), and even New York. The Austro-Hungarian authorities promoted Trieste and Fiume for "their" America-bound migrants, but without much success. Some migrants from the Austro-Hungarian empire circumvented Germany, heading for Italian ports, or Cherbourg and Le Havre. But compared with the migrants who went through Germany their numbers remained small.7 Why avoiding Germany was not an option for most migrants will be explained in the following paragraphs.

7. On Britain and the role of Libau/Liepaja see: Nicholas J. Evans, "Journeys", Migration Histories, http://www.movinghere.org.uk/galleries/histories/jewish/journeys/journeys.htm (accessed 20 July 2006); idem, "The Port Jews of Libau, I880-1914", in David Cesarani and Gemma Romain (eds), Jews and Port Cities, I 590-1990: Commerce, Community and Cosmopolitanism (London, 2006), pp. 197-2 I 4; on pre-I 880 France: Camille Maire, En route pour l'Amérique: L'odyssée des émigrants en France au XIXe siècle (Paris, 1993). 


\section{SCREENING MIGRANTS AND CONTAINING DISEASE}

Ruhleben went into operation in November i 891. It can hardly be described as a "normal" railway station. No passenger was expected to leave the station other than by train. Almost all passengers "arrived" in order to depart as quickly as possible - usually after about one hour, or somewhat longer, if they had to wait for a connecting train. This is why a Berlin journalist characterized the station in 1900 as the "strangest and in more than one respect most interesting railway station of the Imperial capital". ${ }^{8}$

A young Jewish migrant recorded a rare and harrowing description of Ruhleben in its early days. In the spring of 1894 , Mashke Antin, a Jewish teenage girl, left her hometown of Polotzk in the western part of the Russian empire, together with her mother and sister, to join her father, who had moved to Boston two years earlier. After crossing into Germany with some difficulties - a Jewish aid organization helped them across the border after the German border officials had refused them entry - Antin, her mother, and sister boarded an overcrowded emigrant train bound for Berlin. But this train did not stop at any of Berlin's stations. Several miles outside the German capital, the train came to a halt in a deserted area - in Ruhleben. Germans, some in white overalls, rushed the migrants off the train, separated men from women and children, and threw the luggage on a big pile. Antin describes a scene of complete chaos as the bewildered and terrified migrants were driven into a small building. Antin captures the angst which befell the migrants:

Here we had been taken to a lonely place [...]. Our things were taken away, our friends separated from us; a man came to inspect us, as if to ascertain our full value; strange-looking people driving us like dumb animals, helpless and unresisting; children we could not see crying in a way that suggested terrible things; ourselves driven into a little room.

The migrants were forced to undress and washed with a disinfectant soap - only to be quickly hurried back onto the train, which took them to Hamburg. After a fourteen-day quarantine, the family boarded the ship to Boston where they arrived safely two weeks later. ${ }^{9}$

This description of Ruhleben is, of course, well known. In i 899, when she was just eighteen years old, Antin published an English language memoir of her passage from Shtetl to America under the title From Plotzk to Boston. ${ }^{\circ}$ Antin's Ruhleben experience has been quoted by different authors, more recently even in a study on the history of

8. "Moderne Auswanderer", in Berliner Illustrirte Zeitung, 39 (1900), p. 6I 2.

9. Mary Antin, From Plotzk to Boston, with a foreword by Israel Zangwill (Boston, MA, I 899), pp. $4 \mathrm{I}-43$.

Io. Werner Sollors, "Introduction", in Mary Antin, The Promised Land (New York, I997, original edn New York, I913), pp. xi-lvi. 
Auschwitz. ${ }^{\text {II }}$ Nevertheless, the harsh treatment of transmigrants in Ruhleben should not be taken out of its respective context. The screening and disinfection of long-distance migrants, although relatively new at the time, was hardly unique, nor was it a peculiarly German invention or practice. In the same period, American authorities treated Jewish and other European migrants similarly, for the same reason - the fear of contagious disease. ${ }^{\mathrm{I} 2}$

Health checks were a crucial element of the screening procedures at Ellis Island. Only a month after the new American reception centre had gone into operation, a typhus epidemic claimed several victims on New York's Lower East Side in February I 892. The city authorities detained a number of recent Jewish and Italian immigrants, suspected of having been infected with typhus. The migrants were quarantined on a small island near New York under ghastly conditions. Jews were specifically targeted by the authorities and portrayed by newspapers as disease carriers. ${ }^{\mathrm{I}}$

Later in the same year, a cholera epidemic struck parts of central Russia, and the important transatlantic port of Hamburg, claiming more than 8,000 victims. In response, Prussia immediately closed its border with the Russian empire. But since the border could not be sealed, large numbers of migrants made their way to Berlin and the ports. In September I 892, the United States brought transatlantic migration from all European ports almost to a standstill for several months, stranding thousands of migrants. In Hamburg, and again in New York, Jewish migrants were accused of spreading the disease unjustly as two detailed studies on New York and Hamburg have shown. In Hamburg the main cause for the rapid spread of the disease was an inept local government. Berlin and Bremen, also important transit destinations for migrants from Russia, were hardly affected by cholera in $1892 .{ }^{14}$

I I. Antin, From Plotzk to Boston; "Moderne Auswanderer”, p. 6r 2; Irving Howe, World of Our Fathers: The Journey of the East European Jews to America and the Life They Found and Made (New York, 1976), p. 37; Jack Wertheimer, Unwelcome Strangers: East European Jews in Imperial Germany (New York [etc.], I987), pp. 50-51; Deborah Dwork and Robert Jan van Pelt, Auschwitz: 1270 to the Present (New York, 1996), pp. 53-54; Paul Weindling, Epidemics and Genocide in Eastern Europe I890-1945 (Oxford, 2000), pp. 69-7I.

I 2. For a detailed treatment of these procedures in the United States see: Amy L. Fairchild, Science at the Borders: Immigrant Medical Inspection and the Shaping of the Modern Industrial Labor Force (Baltimore, MD, 2003), esp. pp. 53-82; Alan Kraut, Silent Travelers: Germs, Genes, and the "Immigrant Menace" (New York, 1994); Alexandra Minna Stern, Eugenic Nation: Faults and Frontiers of Better Breeding in Modern America (Berkeley, CA, 2005), pp. 57-8 I; for a well researched but inconsistent account of the German disinfection practices for migrants, see Weindling, Epidemics and Genocide, pp. 56-70.

13. Howard Markel, Quarantine! East European Jewish Immigrants and the New York City Epidemics of I 892 (Baltimore, MD, 1997), pp. 28-74.

14. Richard Evans, Death in Hamburg: Society and Politics in the Cholera Years 1830-1910 (Oxford, 1987), pp. 279-284; Markel, Quarantine, pp. 88-I34; Erich Murken, Die grossen transatlantischen Linienreederei-Verbände, Pools und Interessengemeinschaften bis zum Ausbruch des Weltkrieges: Ihre Entstehung, Organisation und Wirksamkeit (Jena, 1922), pp. 56-58. 
In response to the 1892 cholera epidemic, the US Congress passed the I 893 Quarantine Act, requiring the obligatory disinfection of suspicious immigrants before embarkation in Europe, quarantine in the last European port of embarkation - and proof of it. ${ }^{\mathrm{IS}}$ American legislation helps to explain why even migrants from Russia, who had crossed the border illegally evading the German controls, eventually had to enter the transit system at some point because they faced rejection in America, or even at the port of embarkation, without proof of having undergone disinfection and having spent several days in quarantine in Europe. American concerns were a major factor driving the stringent disinfection procedures the Antins experienced in Germany. When Mashke and her family journeyed across Germany, memories of the cholera outbreak along the East-West corridor were still fresh. The harsh treatment of the migrants clearly reflects fear of another outbreak with potentially devastating consequences, not least even more severe American restrictions.

\section{ORIGINS OF THE EAST-WEST TRANSIT CORRIDOR}

The spectre of contagious disease alone does not sufficiently explain the increasing controls and screening procedures which migrants from eastern Europe en route to the United States had to undergo in Germany and across the Atlantic. ${ }^{16}$ Ruhleben went into operation only a few weeks before Ellis Island. Both centres were already screening migrants shortly before the 1892 health scare.

During the I860s and early I870s the United States and Germany transformed into large industrial economies. The rise of global migration in the I 870 s coincided with an important turning point in German migration history. The number of German overseas migrants, bound especially for the United States, began to decline, while Germany emerged as an important destination for labour migrants from eastern and southern Europe. After the early I 870 , internal migrants from rural areas in Prussia, including Poles with Prussian citizenship papers, found work in the rapidly growing industrial centres on the Ruhr, in Upper Silesia, and in Berlin. Poles from the Russian empire were employed as seasonal agricultural labourers. In fact, it was relatively easy to walk across the long border that divided Russia and Austria-Hungary from Germany, but obtaining permanent residence and a work permit was difficult, even if, for instance, a "Russian" Pole married a "German" Pole and wanted to settle in an overwhelmingly Polish area within

I 5. Markel, Quarantine!, pp. I66-I82; on Kontrollnachweis [proof of control] see: Karlsberg, Durchwandererkontrolle, p. 89.

I6. Aristide R. Zolberg, "The Great Wall Against China: Responses to the First Immigration Crisis, I885-1925”, in Leo Lucassen and Jan Lucassen (eds), Migration, Migration History, History (Berne [etc.], 1997), pp. 29i-3is. 
imperial Germany. Only in rare cases eastern European migrants managed to obtain citizenship in Germany. ${ }^{17}$

Faced with rising migration across the eastern border, German state authorities, especially in Prussia, resorted to harsh administrative measures, explicitly refusing to accept immigrants. In the mid-I880s the Prussian government expelled more than 30,000 foreign "Poles" (an estimated i 5,000 were Jews). These mass expulsions were a response to increasing migration from the east and reflect the strong influence of anti-immigrant forces with strong anti-Semitic and anti-Slavic undertones. ${ }^{18}$ The sharp differentiation between Germans and unwanted foreigners - both relatively new categories - was also, however, tied to the origins of the German welfare state in the same period. Persons categorized as non-German aliens by state authorities faced increasing problems finding work and were regarded as a threat to the emerging welfare state. ${ }^{19}$ After protests from large landowners who were deprived of cheap Polish labour, Prussia stopped the expulsions. A thorough work permit and rotation scheme for Polish labour migrants made it hard for illegal migrants to find employment or remain undetected. ${ }^{20}$ Prussia, by far the largest German state, pressured smaller states to follow its lead, resulting in the notorious I9I3 German citizenship law, which based citizenship on descent (ius sanguinis). ${ }^{21}$ Thus Germany "successfully" prevented large-scale immigration before World War I. Transmigration through Germany, however, was a different matter, not least because it represented a highly lucrative business opportunity, especially for Germany's steamship lines. ${ }^{22}$

Rising transmigration from eastern Europe to the West was already alarming the Prussian authorities during the early i 880 . Prussia was Germany's largest state, stretching from the eastern to the western

17. Ulrich Herbert, Geschichte der Ausländerpolitik in Deutschland (Munich, 200I), pp. I4-44; Klaus J. Bade, Migration in European History (Oxford, 2003); Dieter Gosewinkel, Einbürgern und Ausschließen. Die Nationalisierung der Staatsangehörigkeit vom Deutschen Bund bis zur Bundesrepublik Deutschland (Göttingen, 200I).

18. Wertheimer, Unwelcome Strangers, pp. 60-63; see also Bade, Migration in European History.

19. This point requires more research; see Leo Lucassen, "A Many-Headed Monster: The Evolution of the Passport System in the Netherlands and Germany in the Long Nineteenth Century", in John Torpey and Jane Caplan (eds), Documenting Individual Identity: The Development of State Practices in the Modern World (Princeton, NJ, 200I), pp. 235-255, 253; Gosewinkel, Einbürgern und Ausschließen, pp. $225-227$.

20. Herbert, Geschichte der Ausländerpolitik in Deutschland, pp. 14-44.

2 I. Dieter Gosewinkel, "Citizenship and Naturalization Politics in Germany in the Nineteenth and Twentieth Centuries", in Daniel Levi and Yfaat Weiss (eds), Challenging Ethnic Citizenship: German and Israeli Perspectives on Immigration (New York, 2002), pp. 59-75.

22. Murken, Die grossen transatlantischen Linienreederei-Verbände; Ottmüller-Wetzel, Auswanderung über Hamburg; David J. Starkey and Gelina Harlaftis (eds), Global Markets: The Internationalization of the Sea Transport Industries since I850 (St John's, I998). 
German border. In most cases Prussian officials were involved with issues regarding foreign migrants. They checked migrants to make sure that nobody who might become a financial burden to the state crossed the border. But many transmigrants remained undetected because the Prussian state could not control its long eastern border. Since most subjects of the Russian empire, especially Jews and Poles, could not usually obtain Russian passports, they crossed the border illegally and without papers. The Russian government guarded only a few major crossings on its long western border and did little to interrupt the officially illegal departure of hundreds of thousands. Occasionally, Russia refused to readmit "its" citizens who were being deported from Prussia. Since i884, Prussia had required transmigrants to prove that they possessed sufficient funds as well as rail and ship tickets. According to an I885 Prussian decree, every transmigrant coming across the Austrian border had to carry at least 400 Marks (I00 Marks for each child) in cash to finance a possible return journey. Few migrants possessed such amounts; the decree simply allowed Prussian officials to return "problematic" transmigrants. This requirement was already a response to more stringent American policies against unwanted "paupers" who were returned to German ports in the mid-I 880 os. ${ }^{23}$

Most migrants from eastern Europe had to travel through central Berlin to make connections between different railway stations. Disorderly conduct and the strange foreign looks of some migrants waiting at stations became an issue in the local press during the i 880 s. The steady rise of transmigration led to renewed calls to isolate transmigrants. Initial plans for an "emigrant railway station" at Berlin-Ruhleben took shape in early I89i. At the same time, a large barrack complex was built in Hamburg to prevent suspicious transmigrants from staying at various hotels in the city. The issue of disorder, or rather of upholding social order, was of major concern for the Prussian Interior Ministry. Transmigrants were to be removed from public spaces and travel under supervision, so that they could not disturb the civil order. State authorities in Germany and Switzerland opted for similar solutions regarding Italian labour migrants. These were transported to the Ruhr area in separate trains and had to wait in poor quality Italienerbarracken [barracks for Italians] at stations between I 890 and I9I4. ${ }^{24}$ When Ruhleben was already under construction

23. Karlsberg, Durchwandererkontrolle, pp. Iо-38; Hans Rogger, "Tsarist Policy on Jewish Emigration", Soviet Jewish Affairs, 3 (1973), pp. 26-36, 34-36; Ottmüller-Wetzel, Auswanderung über Hamburg, pp. 99-Iог; Antin, From Plotzk to Boston, pp. 24-27.

24. Spandaner Anzeiger für das Havelland, is October I 882 (“disorder"); 8 November I 882 ("fisticuff"); I7 June and I I November I891; Centralblatt der Bawverwaltung [Berlin], 8 April I893, I4, pp. I42f; Jörg Berlin and Matthias Schmoock, Auswandererbafen Hamburg (Hamburg, 2000); Adolf Wennemann, Arbeit im Norden: Italiener im Rheinland und Westfalen des späten 19. und frühen 20. Jabrbunderts (Osnabrück, I995), p. 69. 
during the summer of $\mathrm{I} 89 \mathrm{I}$, the United States reversed its hitherto laissezfaire policy towards immigrants from Europe.

\section{AMERICAN “REMOTE CONTROL”}

In the early I 880 s, the United States too had responded to the increasing immigration of people from around the globe who were not "white" by excluding certain groups from immigration. Immigration policy, hitherto the responsibility of the states, was moved into the domain of the federal government and Congress. The I882 Chinese Exclusion Act explicitly targeted a specific group. In the following years the ban on immigration from China was tightened and Chinese aliens living in the United States were subjected to a number of severe restrictions. Nativist voices in America were calling for the restriction of immigration of other "undesirable" groups. In I 89I, rising immigration, but also Nativist pressures, led to the creation of a new federal administration, the Immigration Bureau - and more stringent controls on America's borders. ${ }^{25}$

Ellis Island was by far the largest of a number of immigration reception centres set up in the wake of the I89I reorganization of US immigration policy. On 2 January I 892 the fifteen-year-old Irish girl, Annie Moore, became the first migrant to enter the new immigration station. This day was her birthday and she was presented with a golden \$10 coin for the occasion. While most of the twelve million immigrants who would follow passed through without much hassle, they were met with more suspicion. Migrants were not only checked thoroughly for contagious disease. Immigration inspectors interviewed them to establish whether they were able to support themselves. "Lunatics", prostitutes, criminals, and not least, persons "likely to become a public charge" were refused entry. Due to pressure from trade unions, "contract labourers" who worked far below average wages were also excluded (if they were discovered).

Before World War I, only third-class passengers had to pass through Ellis Island - first- and second-class passengers were checked only superficially on the ship itself. Admittedly, this system excluded very few Europeans from immigrating to the United States before I9I4, but it served as a blueprint for future immigration restrictions. Especially after I 900 , immigration rates reached record highs. In I904 Jewish migration to the United States crossed the 100,000 threshold for the first time, in 1907

25. Daniel J. Tichenor, Dividing Lines: The Politics of Immigration Control in America (Princeton, NJ, 2002), pp. 87-149; Erika Lee, At America's Gates: Chinese Immigration During the Exclusion Era, I882-1943 (Chapel Hill, NC, 2003); Mae M. Ngai, Impossible Subjects: Illegal Aliens and the Making of Modern America (Princeton, NJ, 2003), pp. 21-56; Aristide R. Zolberg, A Nation by Design: Immigration Policy in the Fashioning of America (Cambridge, MA, 2006), pp. 199-242. 
general net immigration to the United States peaked at I.3 million. Migrants from Asia faced more severe controls. On Angel Island, opened in I9ro in San Francisco Bay, many aliens, mostly Chinese, were interned for lengthy periods. Reception centres such as Ellis and Angel Island were extra legal spaces, serving as precursors to contemporary screening and internment facilities for unwanted migrants at international airports. ${ }^{26}$ In I893/I 894 the United States posted immigration inspectors at Canadian ports to prevent Chinese and European migrants from circumventing immigration controls by crossing the unguarded northern border with Canada. ${ }^{27}$

Many migrants from Europe never reached Ellis Island because it was only one element in a control system that extended to Canadian ports and across the Atlantic. The transatlantic perspective reveals that the rigid German policy towards "suspicious" transmigrants can only be understood fully in the context of the American policy of "remote border control". Aristide Zolberg, who coined this term, traces it back to the early nineteenth century, but links its "triumph" especially with the post I92 I/I924 period, when the United States effectively closed the door to eastern European migrants, forcing transit countries, especially Germany but also Britain and the Netherlands, to deal with the consequences. ${ }^{28}$ But American "remote control" had already made a very major impact during the I 880 s when "suspicious" migrants were rejected at the German-Russian and GermanAustrian borders, or prevented from boarding transatlantic steamships at European ports because the American immigration inspectors might refuse to admit them. ${ }^{29}$

In the I890s, the safeguarding of civil order gave way to a policy of containing unwanted migrants and efficiently handling unsuspicious transmigrants. Only persons who would not be rejected on the western border were admitted across the eastern border. Most transmigrants never really

26. Virginia Yans-McLaughlin and Marjorie Lightman (eds), Ellis Island and the Peopling of America: The Official Guide (New York, 1997), pp. 64-70; Karlsberg, Durchwandererkontrolle, pp. I62-164; Zolberg, A Nation by Design, pp. 46I-474; on Angel Island, see Fairchild, Science at the Borders, pp. I32-1 39; on immigration as "problem", Hiroshi Motomura, Americans in Waiting: The Lost Story of Immigration and Citizenship in the United States (Oxford, 2006). 27. Annual Report of the Superintendent of Immigration to the Secretary of the Treasury (Washington DC, 1894), pp. 17-19; on the background, Marian L. Smith, "The Immigration and Naturalization Service (INS) at the US-Canadian Border, I893-1993: An Overview of Issues and Topics", in Michigan Historical Review, 26 (2000), pp. I 27-I47; Erika Lee, "Enforcing the Borders: Chinese Exclusion along the US Borders with Canada and Mexico, I882-1924", Journal of American History, 89 (2002), pp. 54-86.

28. Zolberg, A Nation by Design, pp. 264-267.

29. Hanseatische Gesandschaft, Berlin, 6 July i 887, State Archive Hamburg, Auswanderungsamt I, 373-7 I [abbreviated as Auswanderungsamt-Hamburg], II E I i; Karlsberg, Durchwandererkontrolle, pp. I $5-35$. 
entered Germany, travelling in an increasingly hermetic transit corridor with no real possibility of leaving the system. The transit corridor was not managed by German state authorities but by the two German steamship lines, the North German Lloyd and the Hamburg-Amerika Line (HAPAG).

\section{GERMAN STEAMSHIP LINES AND CONTROL STATIONS}

The far-reaching impact of American immigration regulations becomes obvious by taking a closer look at the eastern German border. At the very moment that the United States began to step up controls in the mid-I88os, the strong German migration to North America declined and the German shipping lines eagerly embraced the new eastern European passenger market. The repressive Prussian policy against unwanted eastern European immigrants, however, foiled these efforts. Few migrants possessed 400 Marks (as required) and many were arbitrarily rejected near the border or along the way to the ports.

Soon migrants from the Russian and the Austro-Hungarian empires began to circumvent Prussia, travelling in increasing numbers through Vienna or Bohemia, Saxony, and the south German states, to the French, Belgian, and British ports of the western European steamship lines. After protests by the German lines, the Prussian state changed its policy against transmigrants, shortly before also halting the expulsions of unwanted "Poles". After I 887 HAPAG or Lloyd ticket holders could pass without having to prove the possession of 400 Marks. Prussian officials tolerated the illegal crossing of the border by migrants from the Russian empire and their lack of papers, especially if these migrants were customers of a German steamship line. Passengers of the western European lines were treated less favourably in some cases. Without proof of the required 400 Marks and a passport they faced rejection if they came to the attention of the police during the journey through Germany. In I888 Prussia pressured Saxony to step up controls on its border with the AustroHungarian empire, thus closing one bypass route. ${ }^{30}$

The severe crisis of the early I 890 - stricter American access regulations, the cholera outbreak, the (largely unsuccessful) Prussian closure of the Russian border, and the interruption of transatlantic migration - prompted the managers of the German steamship lines to conceive a public-private partnership model that would safeguard their dominance of the eastern European passenger market. In May I894 the director of the HAPAG passenger division, Albert Ballin, and the director-general of North German Lloyd, Heinrich Wiegand, suggested transplanting the Ruhleben model to the eastern border. Some time in I 893 Ruhleben had been

30. Ibid., pp. I 5-20, 35-38; Ottmüller-Wetzel, Auswanderung über Hamburg, pp. Ioof; Caro, Auswanderung und Auswanderungspolitik in Österreich, pp. 59-73. 
equipped with disinfection facilities. Mary Antin's report confirms that migrants were examined and disinfected at Ruhleben in the spring of I 894 .

Ballin and Wiegand now proposed a simple bargain to the Prussian state. The two German lines would manage and finance the transmigration, including all control and disinfection measures required by the United States. Unwanted and ill migrants would be identified at control stations near the main crossing points on the eastern border and immediately rejected without a chance to venture into Germany. Transmigrants would have to enter the control stations voluntarily because they would not be able to board a ship without proof of having passed through a control station. Further control stations at the major railway hub, Leipzig, and at Ruhleben (the only station operated by the Prussian state through the state railway company) would screen transmigrants who somehow evaded the border control stations or crossed the border at little-used crossing points. The lines would cover all potential costs, especially the return journey of rejected migrants (and pocket the profits). They also promised to pay the salaries of local policemen who would guarantee general order at the control stations and would escort rejected migrants back to the border. In return, the Prussian state would protect HAPAG and Lloyd against unwanted competitors. Prussia and the lines reached formal agreement in September i 894. Even before this agreement was signed the United States Immigration Bureau welcomed the new model because Germany was "protecting itself against undesirable immigrants $[\ldots]$ and at the same time protecting us". ${ }^{3 \mathrm{I}}$

The control-station system was an immediate success. The two German lines could direct a large part of the eastern European migration to "their" ports, Bremen and Hamburg respectively. In I902, the state-of-the-art HAPAG Auswandererballen [emigrant halls] replaced the barrack complex at the Hamburg-Amerika dock. The HAPAG Auswandererballen were located at the periphery of the huge Hamburg port, several miles from the city. Transmigrants arrived by train and had to pass a medical inspection and, if necessary, disinfection. They were housed and fed in clean and well-kept buildings, without the possibility of leaving the compound. Jewish migrants had access to Jewish aid workers and received kosher food. The Lloyd also modernized and expanded its facilities in Bremen and Bremerhaven to accommodate the rising number of transmigrants. Thus, the German lines were able to accommodate ever larger numbers of migrants in transit. Their managers had a genuine interest in channelling unsuspicious (and paying) migrants as efficiently as possible from border to port.

3. Albert Ballin to Senator Dr Hachtmann, 30 May 1894; Ministerium des Inneren (Prussia), Agreement with HAPAG and Lloyd, I 8 September I 894, in Auswanderungsamt-Hamburg, II E I Ia 7; Arnold Petzet, Heinrich Wiegand: Ein Lebensbild (Bremen, 1932), pp. 36-40; Annual Report of the Commissioner General of Immigration for the Fiscal Year Ended June 30th, I894 (Washington DC, I894), pp. I3-I4. 
Tellingly, the state did not intervene if employees of the steamship lines rejected migrants in the control stations. If migrants could not prove sufficient funds for a potential return journey, appeared "suspicious", or more importantly, did not have a ticket for a German steamship line, they often could not continue their journey into Germany and enter the transit corridor. This practice unfairly favoured the German steamship companies. Admittedly, not all foreign steamship companies provided the German authorities with guarantees to cover the cost of an eventual return journey for the rejected passengers. By the turn of the century, HAPAG emerged as the world's largest steamship line, thanks to its thriving global freight business, but also because it exploited the eastern European passenger market so successfully. In I 899, Ballin, who was on good personal terms with the Kaiser, was promoted to Director-General of HAPAG. ${ }^{32}$

The main competitors of the German lines, the British Cunard, the Belgian-American Red Star, and the Dutch Holland-America lines tolerated occasional rejections of their passengers by the German lines on the eastern border because they had joined a "pool" or price-fixing cartel that was the brainchild of Ballin. Since the mid-I890s the pool agreement had guaranteed each line a fixed share of migration from the European continent (without Scandinavia, the British Isles, and the Mediterranean). If its share dropped below the negotiated limit, the respective steamship line could claim payments from the other lines. By joining the cartel, the western European lines tacitly recognized the dominance of the two German lines over the eastern European passenger business.

In 1903, against the background of strongly increasing migration from eastern Europe, the Cunard line abandoned the pool, hoping to secure a larger share of the Austro-Hungarian market. An intense price war ensued. For years migrants had been overcharged, now suddenly prices dropped substantially. In 1904 Cunard offered second-class tickets for less than the German lines charged for third class or steerage. Thus, passengers could bypass the dreaded controls on Ellis Island, which applied only to third-class passengers. In response, the German lines began systematically to reject Cunard passengers at their control stations. Most had prepaid tickets sent to them by relatives in the United States. As in the mid-I880s, Cunard advised its passengers to avoid Prussia, travelling via Vienna or Prague, through Bavaria and Frankfurt, to the North Sea and Channel

32. Just, Ost- und südosteuropäische Amerikawanderung, pp. 78-79; also: Ottmüller-Wetzel, Auswanderung über Hamburg, p. 59; Walter Sthamer, Die Auswandererballen in Hamburg (Hamburg, 1904); Jürgen Sielmann, “Haben alle Passagiere auch Geld?’: Zur Geschichte der Auswanderung und des Hamburger Hafens I892-1954", in Karin Schulz (ed.), Hoffnung Amerika. Europäische Auswanderung in die Neue Welt (Bremerhaven, 1994), pp. 85-98; Werner E. Mosse, "Drei Juden in der Wirtschaft Hamburgs: Heine - Ballin - Warburg", in Arno Herzig (ed.), Die Juden in Hamburg I590-1990 (Hamburg, I991), pp. 43 I-446, 435-439. 
ports. The German lines had anticipated such "detours" and were consulting with the Prussian and Bavarian authorities to establish additional control stations at the border with Austria-Hungary and at the main West German railway hub, Frankfurt am Main (which belonged to Prussia). ${ }^{33}$

The rejection of hundreds of migrants on the eastern border triggered growing protests in Germany in the autumn of 1904. The left-wing press was particularly acerbic in its disapproval, but mainstream papers also expressed concern. The Berliner Tageblatt deplored the "unbearable and disgraceful situation" on the border. It described how immigrants in America were advised not send their relatives prepaid tickets from Cunard. Germany's leading left-wing daily, the social democratic Vorwärts, even dispatched an investigative reporter, disguised as an Orthodox Jew from Kiev, through the transit corridor in December 1904. His report was serialized under the title "Mit Ballin Unterwegs" [Travelling with Ballin], and confirmed the arbitrary practices in the control stations, not least the absence of state officials. Tellingly, HAPAG informed the Hamburg authorities, that "our Director-General" had decided to "ignore" the Vorwärts reportage. ${ }^{34}$

Ballin could disregard the press reports because he had reached an agreement with the Cunard line in December 1904. In early i905 the pool agreement was resurrected. The German lines now formally recognized the right of passengers of the large Western lines to use the transit corridor, but only if these steamship lines had obtained a "concession" from the Prussian state. Such a concession was granted if a steamship line pledged to cover all eventual costs that might be caused by "its" passengers. The strong position of the German lines, especially their unrivalled penetration of the Russian and Austro-Hungarian market through an established network of experienced agents, the rise in transatlantic migration after 1905, and large profits made this agreement acceptable. ${ }^{35}$

Even after 1904 the German lines tried to prevent smaller lines from getting a share of the lucrative business. The local government files on the German-Dutch border crossing at Bentheim confirm such unfair practices. In I910, Lloyd and HAPAG advised the Prussian government not to grant a concession to the Dutch-American transatlantic steamship line Uranium. Such a concession would have covered the passage of Uranium passengers through Germany via Bentheim and Rotterdam to New York and back on the same route for rejected migrants. Lloyd and HAPAG

33. Murken, Die grossen transatlantischen Linienreederei-Verbände, pp. 264-282; for a detailed treatment see Karlsberg, Durchwandererkontrolle.

34. Berliner Tageblatt, 27 September (quotation); 4, 6, and 8 October 1904; Vorwärts, 20, 23 ,

27 December 1904, 5, I0 January i905; HAPAG, Abt. Personenverkehr to Kiliszewski, I 2 December 1904, in Auswanderungsamt-Hamburg, II E III P 45.

35. Murken, Die grossen transatlantischen Linienreederei-Verbände, pp. 282-325. 
accused the Uranium line of illegally channelling migrants through Germany and treating them badly. In an internal communication, a high-ranking Prussian customs official in Berlin commented that the German lines made a dishonest case, in order to "eliminate a competitor completely or partially". ${ }^{36}$

For the huge majority of migrants, circumventing the control stations or the German transit corridor was not a realistic option because the long train journey was more expensive than the difference in ticket price. Imperial ports such as Fiume (Hungary), Trieste (Austria), or Libau and even Odessa (Russia) had primitive facilities, limited service, and required paperwork that many migrants either could or did not want to provide (such as young males facing the draft). Migrants who travelled on their own through Germany quickly caught the attention of the police, often with unfortunate consequences. In September I905, small groups of destitute Russian Jews arrived daily at the small railway hub, Bebra in the state of Hesse. Although they had valid train tickets for Antwerp and steamship tickets for New York, the police arrested them because they had evaded the control stations in Leipzig and on the German-Austrian border in Myslowitz in Upper Silesia. The migrants without means were forcibly returned to the eastern border. To blame were apparently "ruthless agents" who had given these migrants wrong advice or cheated them. ${ }^{37}$

The German transit system offered some protection against countless criminals in various guises. Repeatedly, swindlers, who often pretended to be agents of the steamship lines, took advantage of migrants, leaving them without money and with forged tickets at border crossings or train stations. The border crossing between Oświęcim and Myslowitz, the main western gateway for migrants from Galicia, was one of the busiest and most notorious on the east-west transmigration corridor. Already during the mid-I 880 s, the Austrian authorities had uncovered a notorious swindling operation at the Oświęcim railway station. Agents claiming to work for the German steamship lines had cheated thousands of Polish, Ruthenian, Slovak, and Jewish migrants, selling them overpriced and forged tickets. They had also bribed railway officials, customs officers, the local police, and even the regional governor. Large numbers of migrants had been smuggled across the nearby border into Germany. The Hamburg authorities assembled a detailed file on the trial of the Oświęcim "agents" in I889/1890. This illustrates that German state

36. Preußischer Minister des Inneren, Berlin to Regierungspräsident, Osnabrück, 25 June I9Io, in Die unter den Deutschen im Ausland bestehende Rückwanderungsbewegung, Niedersächsisches Staatsarchiv Osnabrück, Rep. 335, No. 13488 [abbreviated as Rückwanderungsbewegung], p. 9; Königliches Preußisches Zollamt (Köhler), Berlin to Landrat, Bentheim, 26 July I9 Io, in ibid., p. I6. 37. Israelitisches Familienblatt (Hamburg), 22 September 1905. 


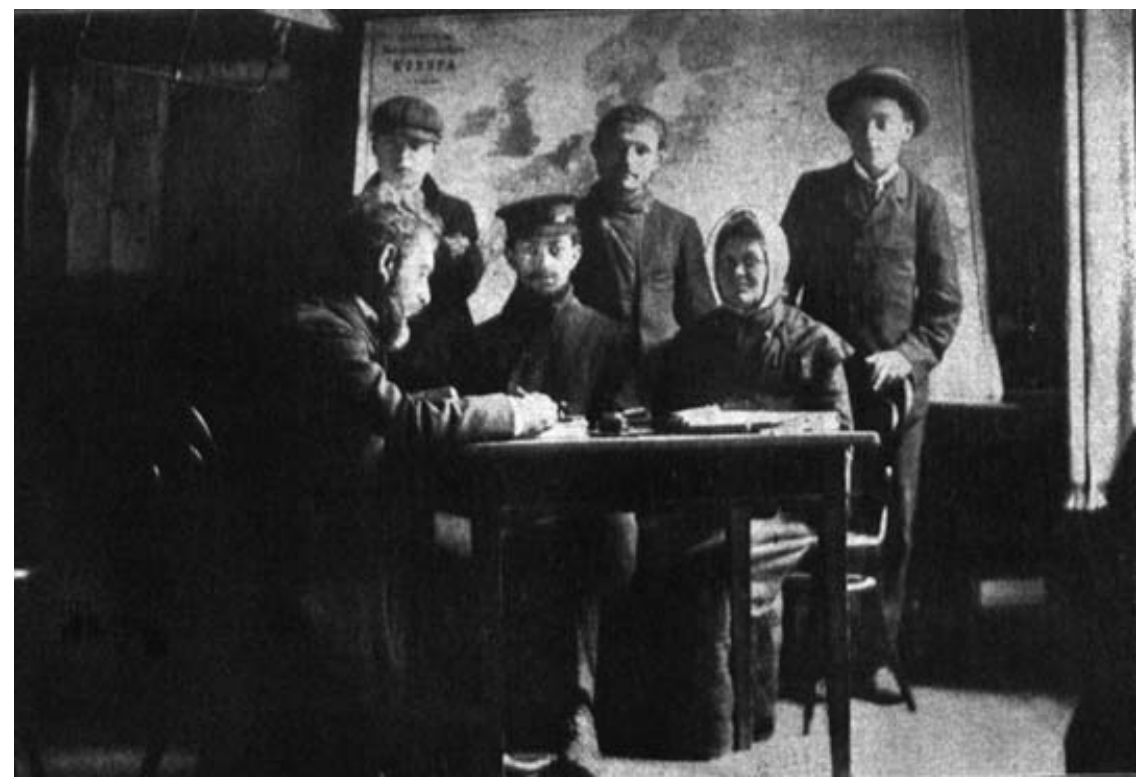

Figure 2. "Giving advice at the [Hilfsverein] central office for Jewish emigration affairs, Berlin”, I906.

Fünfter Geschäftsbericht (1906) des Hilfsvereins der Deutschen Juden (Berlin, 1907), p. I23.

authorities early on closely watched any attempt to undermine the transit and control system. ${ }^{38}$

\section{THE ROLE OF JEWISH PHILANTHROPIC ORGANIZATIONS}

In 1904, the Hilfsverein der Deutschen Juden [Aid Association of German Jews], Germany's leading Jewish philanthropic organization, publicly blamed HAPAG Director-General, Albert Ballin, for the ill-treatment of Jews at the eastern control stations. This attack occurred in a period of mounting criticism towards the rejection of Cunard passengers during the 1904 price war. One year after the notorious Kischinew pogrom, the much-despised Jewish migrants met with a degree of sympathy from the general public. Ballin, who was himself Jewish and repeatedly the target of anti-Semitic abuse, could shrug off protests by Social Democrats, but not the Hilfsverein attack. It was extremely rare that German Jews criticized each other in public. Within days after these reports were published, Ballin met the Hilfsverein leaders, James

38. Caro, Auswanderung und Auswanderungspolitik in Österreich, pp. 59-73; see also the newspaper clippings in "Treiben der oesterr. Agenten in Oswiecim", in AuswanderungsamtHamburg, II A III i b. 


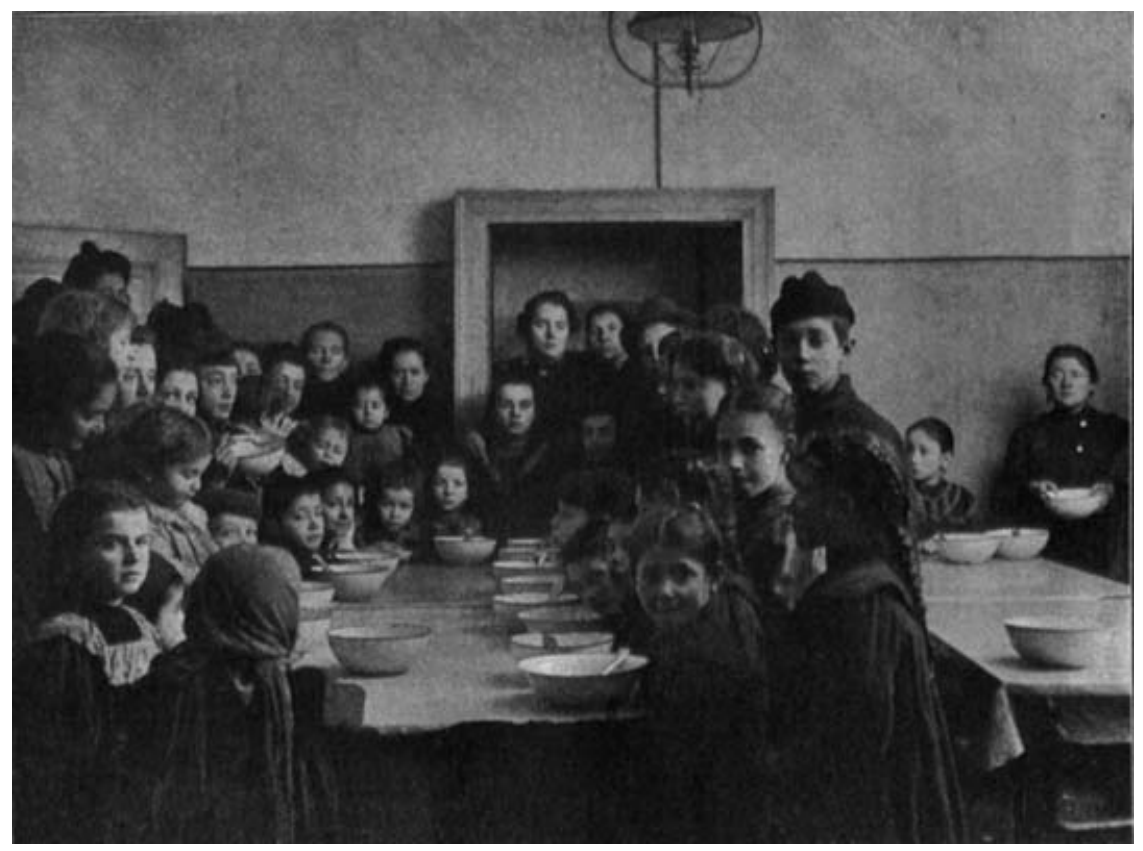

Figure 3. "Lunch at the Hilfsverein hostel in Königsberg", I906.

Fünfter Geschäftsbericht (1906) des Hilfsvereins der Deutschen Juden (Berlin, 1907), p. 138 .

Simon and Paul Nathan, and allowed their representatives permanent access to the control stations. ${ }^{39}$ Non-Jewish migrants also benefited from more transparent procedures.

Transnational Jewish philanthropic associations such as the Hilfsverein did indeed have some impact in protecting, especially Jewish, transmigrants and calling for more transparency. Since the late i 860 , German Jews had organized local aid committees along the east-west travel routes, especially at border crossings and large railway stations. Without the help of a Jewish aid worker stationed on the Russian side of the border, the Antins would not have been able to cross the border, although they had sufficient funds, a passport, and steamship tickets. Members of the Berlin Jewish community were present in Ruhleben since I89I, providing kosher food to transmigrants. Italian seasonal migrants too were supported by grassroots Italian organizations at German stations. ${ }^{40}$

39. 3. Geschäftsbericht (1904) des Hilfsvereins der Deutschen Juden (Berlin, I905), pp. 30ff, 4I; Allgemeine Zeitung des Judenthums [Leipzig], 28 October 1904, p. 529; Im Deutschen Reich [Berlin], November 1904, pp. 6i6f; on anti-Semitic attacks against Ballin, Im Deutschen Reich, August I 899, p. 448.

40. Centralblatt der Bawverwaltung [Berlin], 8 April I893, I4, pp. I42f; Antin, From Plotzk to Boston, pp. 24-27; Wennemann, Arbeit im Norden, p. 69. 
Jewish philanthropic organizations were important forerunners of contemporary transnational NGOs because they combined specific Jewish interests with universal goals, especially minority protection and human rights. The Berlin-based Hilfsverein closely networked with other Jewish aid societies in the United States, western Europe, and the eastern European empires, organizing international conferences and collecting as well as publishing precise data and information that could be of use for Jewish migrants (and is today for scholars working on international migration). The lengthy and detailed annual reports of the Hilfsverein contained numerous photographs and tables proving to its donors and the public that the funds were sensibly invested. ${ }^{4 \mathrm{I}}$

The protective cover of the Hilfsverein, however, had clearly defined limits. Jewish philanthropic organizations successfully guarded the eastwest corridor across the Atlantic, publicizing abuse and ill-treatment of Jewish migrants, but they were not in a position to push for more liberal migration policies. Rather, these organizations attempted to mitigate the effects of harsher policies towards migrants. Hilfsverein representatives repeatedly met government officials in Germany, the Russian empire, and the United States to learn about new policies and to lobby for the interests of Jewish migrants. In I905 Britain, an important transit and destination country, introduced the Aliens Act, which was aimed primarily against Jewish immigrants from eastern Europe (but not strictly enforced before I914). And between 1904 and 1906 Prussia deported hundreds of "illegal" Russian Jewish migrants from Berlin. Although the Russian empire was in state of virtual turmoil in I905 and a wave of pogroms had claimed dozens of Jewish victims, the Hilfsverein leaders worried not only about the desperate situation for Jews in the Russian empire (and Romania). Should America close its doors, the Hilfsverein agonized in I9I I, "a catastrophe would ensue, so terrible, that it will overshadow the persecutions and pogroms". ${ }^{2}$

Even though the Hilfsverein protest forced HAPAG to introduce more transparency in 1904, decisions over rejection at the control stations continued to be made by the steamship line employees, not by state officials. In April ig05 a Jewish couple from Russia committed suicide at

4I. Mark Wischnitzer, "Die Tätigkeit des Hilfsvereins in der Nachkriegszeit", in Festschrift anlässlich der Feier des 2 sjährigen Bestehens des Hilfsvereins der Deutschen Juden, gegr. am 28. Mai I90I (Berlin, I926), pp. 47-58; Tobias Brinkmann, "Managing Mass Migration: Jewish Philanthropic Organizations and Jewish Mass Migration from Eastern Europe, I 868/69-I9I4", Leidschrift, 22 (2007), pp. 71-90.

42. Ibid.; Allgemeine Zeitung des Judenthums [Berlin], I3 April 1906, p. I71 (c. 6,500 Jews were deported from Berlin); Wertheimer, Unwelcome Strangers, p. 6I; Just, Ost- und südosteuropäische Amerikawanderung, p. 90; 9. Geschäftsbericht (I9I0) des Hilfsvereins der Deutschen Juden (Berlin, I9I I), p. I40. 
the Ostrowo control station after they were turned back because of insufficient funds. The Vorwärts sarcastically remarked that these "Ballin Opfer" [Ballin's victims] were actually too poor to be "exploited" by Ballin. In August the Vorwärts reported another rejection case with the headline "Gesetz Ballin" [Ballin's Law], complaining about the total lack of legal protection for migrants, who were at the mercy of a private company at the control stations. ${ }^{43}$ In spring I 905 the leaders of the Social Democratic opposition raised the treatment of migrants at the control stations in the Reichstag parliament. MP Hugo Haase described the control stations as "Menschenfallen" [traps for humans], criticizing the exploitation of "poor tortured souls" by the steamship lines. ${ }^{44}$

The private handling of the border controls increased the effectiveness of the American remote control system. Any change in immigration regulations were transmitted and readily executed by companies interested in smooth and well-organized procedures. The profitable business depended almost entirely on American access rules, only to a lesser extent on the immigration policies of other destination countries such as Britain, Canada, or Argentina. The German authorities were only too happy to leave the details of control and the organization of the transit to private companies, as long as migrants did not escape from the transit corridor or became a financial burden.

Until I9I4 only few loopholes remained in the transit corridor. In 1907, the Dillingham Commission of the United States Congress, composed of several parliamentarians and public figures in favour of much more stringent immigration restrictions, inspected several German control stations. They even sent an investigator disguised as a migrant through the German transit corridor. The commission was clearly impressed, describing the control stations in the final report as "one of the most interesting instances of emigrant inspection in Europe", and noting with satisfaction that "every year thousands are turned back". ${ }^{45}$ In most other European countries the commission observed far less satisfactory inspection procedures. In the Austro-Hungarian port, Fiume, the American consul screened boarding passengers together with a physician employed by the Cunard line. But the rejection rates of passengers arriving from Fiume at Ellis Island remained high. ${ }^{46}$

43. Vorwärts [Berlin], I May 1905 and i9 August 1905.

44. Quoted after Just, Ost- und südosteuropäische Amerikawanderung, p. 80.

45. Emigrant Conditions in Europe, in 6ist Congress, 3rd Session, Senate, Reports of the Immigrant Commission, presented by Mr Dillingham (Washington DC, I9II), pp. 93-97 (quotation p. 93).

46. Dorothee Schneider, "The United States Government and the Investigation of European Emigration in the Open Door Era", in Nancy Green and François Weil (eds), Citizenship and Those Who Leave: The Politics of Emigration and Expatriation (Urbana, IL, 2007), pp. 195-2 10, 203-204. 


\section{WEST-EAST TRANSMIGRATION}

The east-west transit corridor was not a one-way street. Migrants also travelled from west to east: persons who had been refused entry by American immigration inspectors, but also return migrants who arrived at Hamburg or Bremen, or at the German border with the Netherlands, Belgium, or France. In I910 the Hilfsverein reported an increase in rejections at New York, "the implementation of the immigration laws has already been strange in many instances, and harsh, now it has become even more ruthless". ${ }^{77}$ The above-mentioned files on the German-Dutch border crossing at Bentheim do indicate a rise in rejections. In the fall of i9ıо, policeman Rebenklau at Bentheim reported five transports between mid-September and midNovember, each with several hundred eastern European passengers of Dutch steamship lines who had been refused admission in the United States. ${ }^{4}$ Nevertheless, relatively high rejection rates also reflect strongly increasing immigration to the United States in I9I0.

Occasionally, migrants without means were stranded on the GermanDutch border after having been returned by the United States to Rotterdam. German officials deported such destitute migrants repeatedly back across the border to the Netherlands, refusing to cover the cost of the transit through Germany. The Prussian concession obliged representatives of the Dutch steamship line to accompany sealed trains with "its" rejected passengers through Germany from Bentheim to the eastern border crossing with Russia or Austria. Sometimes migrants escaped from the train or disappeared, triggering frantic search operations, which appear to have involved primarily German railway officials. Repeatedly, the local government official in Bentheim sent circulars to every major station along the east-west corridor to ask for assistance in tracing transmigrants, who had "escaped". In one case, a Dutch agent employed by the Dutch-American Uranium line, recounted his desperate search for three migrants in the small East Prussian town of Soldau. ${ }^{49}$ Clearly, the Uranium line was afraid of being stripped of its valuable Prussian concession because it had "lost" transmigrants during the German transit. The unsuccessful searches also indicate that the west-east transit corridor was much less hermetic than the east-west corridor. Until igi4 only one local policeman (who was sometimes supported by a colleague) could be

47. 8. Geschäftsbericht (1909) des Hilfsvereins der Deutschen Juden (Berlin, I910), p. I I3. 48. Rebenklau (ı. Gendarmerie Brigade), Bentheim to Landrat, Bentheim, I4 and 28 September, Is and 28 October, 25 November 1910, in Rückwanderungsbewegung, pp. 28-44. 49. The Uranium Steam Ship Co., Rotterdam to Landrat, Bentheim, 26 May I9II, in Rückwanderungsbewegung, p. I 37 (Soldau incident); Preußischer Minister des Inneren, Berlin to Regierungspräsident, Osnabrück, Is April I9I2; Regierungspräsident, Osnabrück to Königliche Eisenbahndirektion Hannover, 2I April 1912, in Rückwanderungsbewegung, pp. $28 \mathrm{I}-297$. 
found at the relatively busy Bentheim crossing, also proof of a relatively limited state presence on the outer German border. ${ }^{50}$

\section{PERMANENT TRANSIT}

Before I9I4 most eastern European migrants bound for the United States and other overseas destinations could expect to arrive at their destination within a few weeks. But from the I 890 s they were subjected to increasing controls, partly as a result of more restrictive American immigration policies, partly because of the refusal of the German state to accept immigrants. At the very moment most eastern European migrants left their home villages they stepped into an extra-legal space where they were deprived of agency. Private steamship companies especially had enormous leverage over their fate. Once migrants entered the east-west corridor by crossing the German border they could be returned, or worse, without explanation at any time. The small train crash in Berlin led to a rare and brief intersection between the spaces of transmigration and Berlin public life. The bewildered reactions in the press illustrate the degree of isolation imposed on transmigrants. The migrants had firm ground under their feet (in a legal sense) only when were admitted at Ellis Island (or in western Europe). While the number of rejected migrants at Ellis Island remained relatively small before 1914, many more were returned before they even reached the European port of embarkation, especially at the German borders with the Russian and Austro-Hungarian empires. The Ostrowo suicide hints at the torment which befell many of these migrants. Little is known about their fate, let alone precise numbers.

The control station system yielded huge profits for the German steamship lines. Yet transmigrants were offered - admittedly for a price - a relatively smooth passage from the German border to an overseas destination. Ironically, the control-station system increased the chances of migrants passing the American inspection at Ellis Island. The superficial screening measures at Fiume and other imperial ports made a rejection at an American (or Canadian) port more likely. And the transit through Germany had another advantage over the imperial ports: by crossing the open land border to Germany migrants could avoid the attention of imperial state officials.

The success of HAPAG was a major factor behind Hamburg's rise to become one of the most important global ports around the turn of the century. The massive expansion of the port, rapid industrialization, and population growth sidelined Hamburg's erstwhile rival, Bremen. Nevertheless, the Lloyd line remained a formidable player. While the western European and British lines largely concentrated on the North Atlantic,

50. See, for instance, Regierungspräsident Osnabrück to Landrat Bentheim, 25 November I9I I, in Rückwanderungsbewegung, p. 228. 
the two German lines expanded their passenger and freight business around the globe. The two lines largely divided the eastern European market: HAPAG dominated the Russian passenger business, while Lloyd successfully expanded its control over migration from the Austro-Hungarian empire. ${ }^{\text {II }}$

The "Great War" interrupted transmigration almost completely. Overnight open borders turned into military front lines. Most Europeans faced massive internal mobility restrictions, or they were "moved" against their will. In I9Is the Russian authorities forcibly "resettled" thousands of ethnic Germans and Jews as potential collaborators. Soon hundreds of thousands became refugees, fleeing military conflicts and persecution across eastern Europe. Germany deported thousands of Poles and Jews from areas under its control as forced labourers for its war industries. A few managed to find a way out: the German military authorities in Warsaw and Kowno allowed small numbers of Jewish migrants passage through Scandinavia to the United States before 1917..$^{2}$

In the wake of the collapse of the empires, large areas of eastern Europe experienced intense warfare long after I9I 8 . At least 60,000 Jews were killed in Poland and the Ukraine in 1918/1919; many more were permanently displaced. After the war, refugees and migrants faced substantial obstacles. $\mathrm{New}$ and shifting borders and violence in east central Europe were not the only problem. ${ }^{53}$ In the first months after November 19i 8, several of Germany's western border crossings and the transatlantic ports were closed by the Allied powers, and transmigration resumed only slowly. More decisive was the end of the laissez-faire era in transatlantic migration. The international passport and identity-control system created new categories of people: illegal immigrants and - the stateless. Many Jews and other eastern Europeans lost their citizenship with the collapse of the empires, without automatically receiving a new one. The rise of identity control was closely tied to the instability of the international system after i9i 8 . Immediately after the war, for instance, western European countries like the Netherlands

51. Murken, Die grossen transatlantischen Linienreederei-Verbände, pp. 282-322.

52. Eric Lohr, Nationalizing the Russian Empire: The Campaign against Enemy Aliens during World War I (Cambridge, MA, 2003); also Peter Gatrell, A Whole Empire Walking: Refugees in Russia during World War I (Bloomington, IN, I999); David Rechter, The Jerws of Vienna and the First World War (London, 200I); Leon Sklarz, Geschichte und Organisation der Ostjudenhilfe in Deutschland seit dem Jahre 1914 (Berlin, 1927), p. 72.

53. Carole Fink, Defending the Rights of Others: The Great Powers, the Jews, and International Minority Protection, $1878-1938$ (Cambridge, 2004), pp. IOI-I30; Lloyd P. Gartner, History of the Jews in Modern Times (Oxford, 200I), pp. 282-286; Jochen Oltmer, Migration und Politik in der Weimarer Republik (Göttingen, 2005), pp. 238-250; Kulischer, Europe on the Move, pp. I34f, I7I, I76; Michael R. Marrus, The Unwanted: European Refugees in the Twentieth Century (Oxford, 1985), pp. 52-80; Josef Neuberger, Die Hauptwanderungen der Juden seit I9I4 (Cologne, I928), p. 40; Steinert, "Berlin - Polnischer Bahnhof!", pp. 249-256. 
and Belgium demanded transit visas, making the migration from eastern Europe to North America more difficult. ${ }^{54}$

The Russian Revolution, the short lived left-wing takeovers in central and eastern Europe, the huge number of displaced persons in Europe, but also a postwar economic recession provided the opponents of relatively open immigration into the United States with the decisive momentum. In I92 I and I924, Congress effectively closed America's doors to immigrants from the major pre-I9I4 sending countries. Immigration from southern and eastern Europe as well as Asia was reduced to a trickle compared with the high pre-war levels. The basis for the notorious national quotas was citizenship. No quota was reserved for Jews and other transterritorial diaspora groups, let alone for stateless persons. The I 924 act shifted the responsibility for admission from the immigration officer at the port of entry to the consular officer in the immigrant's country of origin. The application had to be sent to the State Department before a visa was issued (or refused). These administrative procedures literally deprived many migrants of mobility.

As migrants looked for alternatives to the United States, other destination countries such as Argentina and Canada tightened their migration policies. Britain never abolished the restrictions regarding immigration imposed in I9I4. ${ }^{55}$ Under the new American regulations, any migrant with valid papers, a visa, and a steamship ticket could get on board. The lengthy visa application and rigorous checks at the American embassy or consulate replaced the inspection at Ellis Island and by the German steamship lines. Admittedly, the near total loss of the eastern European business affected HAPAG and Lloyd much harder than the loss of their pre-war role as arbiters over granting access to America. The post-I9I7 history of Ellis Island symbolically illustrates the restrictive turn in American immigration policy. When the United States entered the war, the reception centre reversed its function. Several enemy aliens and other suspicious foreigners were interned on the island. In I9I9, a number of prominent left-wing immigrant radicals were stripped of their citizenship, briefly detained at Ellis Island, and deported to Europe. From I9I7 until its closure in I954, Ellis Island served primarily as detention facility for suspicious or unwanted aliens, many awaiting deportation. ${ }^{56}$

54. John Torpey, "The Great War and the Birth of the Modern Passport System", in idem, Documenting Individual Identity, pp. 256-270, 264; Korrespondenzblatt des Centralbüros für jüdische Auswanderungsangelegenheiten des Hilfsvereins der Deutschen Juden [Berlin], August/ September 1922; August/September 1923.

55. Tichenor, Dividing Lines, pp. I 38-I 46, I 50-I67; Zolberg, A Nation by Design, pp. 25 I-270; Korrespondenzblatt des Centralbüros für Jüdische Auswanderungsangelegenheiten des Hilfsvereins der Deutschen Juden [Berlin], April 1924; for Britain, see Tony Kushner and Katherine Knox, Refugees in an Age of Genocide (London, 1999), pp. 19-102.

56. Richard Drinnon, Rebel in Paradise: A Biography of Emma Goldman (Chicago, IL, I982); Hebrew Sheltering and Immigrant Aid Society of America (HIAS), Nineteenth Annual Report 1927 (New York, I928), p. 9. 
Germany pursued a less restrictive migration policy after i9i 8, partly as a result of the American closed-door policy, which stranded many migrants along the east-west corridor. Initially, the Weimar Republic was simply not in a position to deport large numbers of refugees and stranded migrants, nor to police its new borders. After the republic had stabilized, it did not want to cause offence to its western neighbours by deporting destitute refugees to the east. By the mid-I920s, when military conflicts had ceased, refugees were increasingly "returning" - to countries that had not existed when they had left. France partly replaced the United States as an important immigration country for eastern and southern Europeans. A few managed to reach far-flung destinations such as Buenos Aires or Harbin. 57

For a short time between I9I 8 and I92 I the transmigration system seemed to recover, albeit slowly. The steamship lines again organized transports to their ports. Transit points, which had been less important before I9I4, experienced a sudden rush of activity. The initial Allied restrictions on Hamburg and Bremen turned Danzig in particular into an important transatlantic port for emigrants. But after I92 I the numbers recorded by Jewish migrant aid societies sharply declined. HAPAG and Lloyd never fully recovered from severe wartime losses and postwar restrictions. Just when the steamship traffic from Hamburg and Bremen gradually resumed, American immigration restrictions deprived them of the bulk of their business. Albert Ballin did not live to see the complete destruction of the system he had helped to create. He died in what may have been a suicide, two days before Armistice Day, on 9 November 191 8, the day Germany became a republic. ${ }^{5}$

Before the east-west transit corridor through Germany could be fully restored, American immigration restrictions stopped the movement. Millions of unwanted migrants and refugees were stranded in international space, between real borders and often insurmountable "paper walls". Points of passage were replaced by points of permanent transit. Refugee camps and makeshift barracks became a common sight across

57. Ministerium des Inneren (Deutsches Reich), Ergänzung zum Erlaß, I June I920, Auswärtiges Amt, Abt. A, IVb 3095, German Foreign Ministry Collection, Leo Baeck Institute Archive (New York); Clifford Rosenberg, Policing Paris: The Origins of Modern Immigration Control Between the Wars (Ithaca, NY, 2006), pp. 17-44; on Argentina, Australia, and other alternative destinations, see Korrespondenzblatt des Centralbüros für jüdische Auswanderungsangelegenheiten des Hilfsvereins der Deutschen Juden [Berlin], August/September 1922 and April ig24.

58. Wischnitzer, Die Tätigkeit des Hilfsvereins, p. 50; Wischnitzer, To Dwell in Safety, pp. I46-I48; Korrespondenzblatt des Centralbüros für Jüdische Auswanderungsangelegenheiten des Hilfsvereins der Deutschen Juden [Berlin], August/September 1922; Murken, Die grossen transatlantischen Linienreederei-Verbände, pp. 629-63I. 
Europe. Eastern European transmigrants often spent months, even years, waiting for papers or searching for alternative destinations. ${ }^{59}$

Two important pioneers of migration history, the Russian Jewish brothers, Eugen and Alexander Kulischer, commented in 1932 in Berlin:

With this catastrophe [the "Great War"] the era of large anarchic and free migration has come to an end. [...]. The Gate of the Promised Land, which presented itself as asylum of the poor and persecuted of this world, has closed with a loud bang, and it is ever more tightly locked. But at the same time, many new immigration restrictions and work restrictions have been enacted along many old and new borders in Europe.

It would indeed be too simplistic to put the blame for cutting off a major artery of global movement entirely on the United States. Post-I9I 8 migration restrictions were a global phenomenon and a symbol for the crisis of the international system, not least the inability to address sufficiently the plight of millions of refugees across Europe. No phenomenon better illustrates the loss of trust between nation-states than the rise of the passport as the new "currency" of movement between and across national borders - and the desperate fate of the stateless who did not possess "papers". 60

59. David S. Wyman, Paper Walls; America and the Refugee Crisis, 1938-I94I (Amherst, MA, 1968); Marrus, The Unwanted; Joseph Roth, Juden auf Wanderschaft (Berlin, 1927); Martin Beradt, Street of Small Eternity (Frankfurt, 2003); on post-war Vienna, Beatrix HoffmannHolter, “Abreisemachung” - Jüdische Kriegsflüchtlinge in Wien I9I4 bis 1923 (Vienna, 1995), pp. $225-27$ I.

60. Kulischer, Kriegs- und Wanderzüge, pp. 20If; Torpey, The Great War, p. 270. 